\section{Assessment mismatches must be sorted out: they leave species at risk}

Sir - Although Rodríguez et al. are correct that nationally endemic taxa should be classified identically on national and global Red Lists ${ }^{1}$, they provide no evidence to support their inferences that national Red Lists "are more accurate" than global Red local data". Moreover, we see certain problems with the national Red Lists they analyse which suggest these inferences may be mistaken.

Only nine of the 70 different assessments tabulated by Rodríguez et al. are due to different information about species. IUCN assessors and the national assessors over the choices of taxa for consideration - especially taxa from groups such as reptiles, amphibians, bony fishes and invertebrates, which IUCN has only partially considered $^{2}$ - and the inclusion of subspecies, which have not been a major focus of the IUCN Red List. Seven species were listed as Data Deficient on the national lists, whereas for the global list the same information was considered adequate to place them in a threatened category. Of particular concern are the cases resulting from inconsistent use in the national lists of the IUCN Red List Criteria ${ }^{3}$ (see Table 1).

Many of these inconsistencies are compounded by national Red List assessments not making their use of the Red List Criteria explicit for each taxon, as required ${ }^{3}$, and/or failing to provide supporting information (despite the claim that national Red Lists utilize a "wealth of local data", the Argentine $^{4}$ and Ecuador ${ }^{5}$ lists contain no supporting data whatsoever).

At present IUCN recommends that experts making assessments for the global Red List should consult national authorities in reaching a decision. IUCN would like to move rapidly towards a situation where the national assessments could be used without any intermediate steps to ensure Lists, or that global lists ignore a "wealth of Thirty-two result from differences between

standardization of approaches. To this end IUCN has established two key initiatives.

First, to improve information flow and quality, IUCN is appointing Red List Authorities (RLAs) who will ensure that all assessments are done in a fully consultative manner and are well documented and peer reviewed (a model established by BirdLife International $\left.{ }^{6,7}\right)$. The RLAs will have access to shared databases of species information that will be based in part on interactive web technologies (see http://www.iucn.org/ themes/ssc/programs/sis. htm).

Second, IUCN aims to improve consistency in the use of the Red List Criteria. It is running a series of regional Red List workshops around the world: the first, held in Sri Lanka in September 1999, involved participants from 12 Asian countries. Other workshops are planned for Mesoamerica, South America, southern Africa and east Africa. IUCN is also recommending and distributing standard computer software ${ }^{8}$ that takes assessors systematically through the categorization process. Progress in all this is constrained only by resources.

Craig Hilton-Taylor ${ }^{\star}$, Georgina M. Mace $\dagger$, David R. Capper $\neq$, Nigel J. Collar $\ddagger$, Simon N. Stuart $\$$, Colin J. Bibby $\ddagger$, Caroline Pollock ${ }^{\star}$, Jørgen B. Thomsenll

${ }^{*}$ IUCN/SSC UK Office, 219c Huntingdon Road, Cambridge CB3 ODL, UK

†Institute of Zoology, Zoological Society of London, Regent's Park, London NW1 4RY, UK

$\ddagger$ BirdLife International, Wellbrook Court, Girton Road, Cambridge CB3 ONA, UK

\$IUCN/SSC, Rue Mauverney 28, Gland CH-1196, Switzerland

IConservation International, 2501 M Street, NW, Suite 200, Washington, DC 20037, USA

1. Nature 403, 241 (2000).

2. Baillie, J, \& Groombridge, B. (eds) 1996 IUCN Red List of Threatened Animals (IUCN, Gland, 1996)

3. IUCN Species Survival Commission IUCN Red List Categories (IUCN, Gland, 1994).

4. García Fernández, J. J., et al. Libro Rojo de Mamíferos y Aves Amenazados de la Argentina (Fundación para la Conservación de las Especies y el Medio Ambiente, Buenos Aires, 1997).

5. Granizo, T. M. et al. Lista de Aves Amenazadas de Extinción en el Ecuador 1-31 (UICN-Sur, CECIA, INEFAN, EcoCiencia y BirdLife International, Quito, 1997).

6. Collar, N. J. et al. Threatened Birds of the Americas: the ICBP/IUCN Red Data Book (International Council for Bird Preservation, Cambridge, 1992).

7. Collar, N. J., Crosby, M. J. \& Stattersfield, A. J. Birds to Watch 2:

Table 1 Reasons for disparities between threatened endemic animal taxa (Critically Endangered, Endangered and Vulnerable) on the IUCN global Red List and on national Red Lists

\begin{tabular}{|c|c|c|c|c|c|c|}
\hline \multirow[b]{2}{*}{ Number of threatened taxa on both lists } & \multicolumn{5}{|c|}{ Taxa } & \multirow[b]{2}{*}{$\begin{array}{l}\text { All } \\
40\end{array}$} \\
\hline & $\begin{array}{r}\mathrm{Mam} \\
8\end{array}$ & $\begin{array}{r}\text { Birds } \\
30\end{array}$ & $\begin{array}{r}\operatorname{Rep} \\
1\end{array}$ & Amph & $\begin{array}{r}B F \\
1\end{array}$ & \\
\hline Species not assessed by IUCN & 1 & & 1 & 7 & 7 & 16 \\
\hline Species on IUCN but not national lists & 4 & & & & 3 & 7 \\
\hline Sub-specific taxa not assessed by IUCN & 2 & 4 & 1 & & & 7 \\
\hline Sub-specific taxa on IUCN but not national lists & 2 & & & & & 2 \\
\hline Different use of categories on national lists & 2 & 4 & 1 & & & 7 \\
\hline Different use of criteria on national lists & 7 & 15 & & & & 22 \\
\hline Different information used for listings & 3 & 6 & & & & 9 \\
\hline Total number of threatened taxa & 29 & 59 & 4 & 7 & 11 & 110 \\
\hline
\end{tabular}

The World List of Threatened Birds (BirdLife International, Cambridge, 1994).

8. Akçakaya, H.R. \& Ferson, S. RAMAS Red List: Threatened Species Classifications Under Uncertainty, Version 1.0 (Applied Biomathematics, New York, 1999).

9. Ergueta, P. \& de Morales, C. (eds) Libro Rojo de los Vertebrados de Bolivia (Centro de Datos para la Conservación, La Paz, 1996). 10. Rodríguez, J. P. \& Rojas-Suárez, F. Libro Rojo de la Fauna Venezolana 2nd edn (PROVITA, Fundación Polar, Wildlife Conservation Society, PROFAUNA-MARNR, UICN, Caracas, 1995).

\section{Fooled, but not foolish}

Sir - References to National Geographic in your Opinion article "Fossil Smuggling Unopposed"1 are false. The article on new dinosaurs from China was not "naively and hastily" published. It had been in preparation for a full year before publication and during this time was reviewed by six leading paleontologists and ornithologists.

Pertinent information concerning the integrity of the specimen known as Archaeoraptor was not made available to us or to them before publication. National Geographic is sparing no effort to investigate all issues raised concerning this specimen.

I also take strong exception to the anonymous quote in your editorial. That statement, which implied that our reporting was biased, was made by a person who is known to be a vocal opponent of the dinosaur-bird theory.

There is no question that a major problem in the field of palaeontology is the commercial trade in fossils. National Geograph$i c$, for its part, has a policy of not photographing or writing about fossils that are of illegal status, and we did not consider including Archaeoraptor in the article until assured it would be returned to China. We are proud of National Geographic's role in that process.

William L. Allen

National Geographic Magazine, 1145 17th Street, Washington, DC 20036

1. Nature 403, 687 (2000).

\section{How much use is the Human Genome Project?}

Sir-Current hype about the expected completion of the Human Genome Project demands some clarification of the details as well as of the wider scientific implications. Although initially conceptualized more broadly, the project is effectively about determining the sequence of bases in the human genome. This is not the same as trying to understand the program that is encoded in human DNA, an obvious requirement for any pharmacological application. Consequently, the results will be in the merely descriptive naturalistic 
tradition (along the lines of 'the mean content of bases $\mathrm{G}$ and $\mathrm{C}$ of sequence soand-so is 47.8 per cent'). Technical development has always had that effect on scientific disciplines, for example the electron microscope, the radio telescope or the automated DNA sequencer.

Of course, researchers are always quick to emphasize the importance of their work to whatever application is in vogue, and curing diseases is a worthy goal. But how specifically will the Human Genome Project help to achieve this end? A look at any gene (as opposed to a sequence) map from any species reveals what looks like an explosion in a slaughterhouse. Where is the order we need, to make sensible rather than trialand-error genetic manipulations?

Should scientists' claims of applicability for their results be acknowledged as a mechanism to secure funding rather than having any realistic basis? 'Science is a process and not a series of final states' is the somewhat trite argument to justify goals not achieved. A series of simple descriptive, but highly technical, publications ensures that research money will be channelled into well-trodden paths in the future.

In any case, pharmacogenomics requires an understanding of the apparent genetic 'disorder' in any organism's genome, of genotype-phenotype mapping, of gene-gene interactions (epistasis), of intraspecific genetic variability, and of self-organizational processes, rather than endless lists of DNA bases.

\section{Sol Hadden}

Advisory Council for Advanced Concepts, 206 Rhodes Hall, Cornell University,

Ithaca, NY 14853, USA

\section{Genes: we can't expect full understanding yet}

Sir - The editing of one phrase in our statement about ownership of the human genome $^{1}$ might lead readers to misconstrue our intention. In the sentence printed as "The intention of some university and commercial interests to patent the DNA sequences themselves, thereby staking claim to large numbers of human genes without necessarily having a full understanding of their functioning, strikes us as contrary to the essence of patent law", the word "full" should have been deleted.

In fact, the full understanding of a gene is likely to take many decades to accomplish, and such a criterion would clearly be unreasonable with respect to what is patentable. Our point is that some level of understanding of specific function is important before a patent is awarded, as this is a necessary precursor to the claim of a substantial utility.
We also wish to comment that it is not the case, as implied in the Opinion article in the same issue ${ }^{2}$ that the main target of our statement was Celera Genomics. We were addressing important issues of broad public policy, and our focus was primarily the patent offices and the law courts, in which the validity of claims for genesequence patents will be decided. Bruce Alberts ${ }^{\star}$, Aaron Klug $\dagger$

${ }^{*}$ National Academy of Sciences, 2101 Constitution Avenue NW, Washington DC 20418, USA

$\dagger$ Royal Society, Carlton House Terrace, London SWIY 5AG, UK

\section{Nature 404, 305 (2000).}

2. Nature 404, 317 (2000).

\section{Garlic study vindicated by official investigation}

Sir - Your News story "German garlic study under scrutiny" " reports allegations of data manipulation and incorrect data analysis raised in a German newspaper about a study we carried out using a garlic preparation called Kwai. They were made after the results of our clinical study "Randomized placebo-controlled doubleblind study on antiatherosclerotic effect of Kwai in common carotid arteries and femoral arteries" were published ${ }^{2}$.

As mentioned in your story, an official committee at Humboldt University was set up to investigate the claims of falsification. It has now announced that the accusation of data manipulation is unfounded.

The investigating committee has found that the clinical trial had been sanctioned in advance by the relevant ethics committee and that the patients had agreed individually, in writing, to participate. The use of an alternative statistical evaluation was explained in detail in our original article ${ }^{2}$, but we have clarified this matter in a letter to the same journal ${ }^{3}$.

We have also confirmed the plaque reduction reported in our published article $^{2}$ by two more ultrasound photos of the same patient from the verum group (with initials and date at the same examination time) using the sector scanner, a different ultrasound system (data not shown). We have examined and confirmed the reproducibility of our earlier ultrasound photos, and we will present our confirmatory findings in a future article.

J. Koscielny, R. Schmitt, H. Radtke, R. Latza, H. Kiesewetter

Institute for Transfusion Medicine, Medical Faculty Charité, Humboldt University, Campus Charité Mitte, Schumannstr. 20/21, D-10117 Berlin, Germany
1. Nature 401, 629 (1999).
2. Koscielny, J. et al. Atherosclerosis 144, 237-249 (1999).
3. Siegel, G. Atherosclerosis 148 (in the press).

\section{Learn lateral thinking first and specialize later}

Sir — Frederick Seitz's Millennium Essay, "Decline of the generalist"1, voices an important truth about narrow specialization in science. The twentieth century was the age of scientific specialization, and in many areas this will continue.

However, the pendulum begins to swing back. Nature readers can hardly have overlooked those systems that today challenge science and society: geophysiological systems of ocean, weather and global warming; biophysical-mathematical systems such as brain function and animal behaviour; and other natural systems, large and small. All of these trample briskly across traditional scientific boundaries. So is there not a new urgency about the interand multidisciplinary teaching of science? Should we not prepare science graduates whose careers will take other directions to understand something of the science and technology that will dominate their world?

General and specialist aims in scientific education are not incompatible. The answer is to offer university science courses broad enough to encourage lateral thinking across two or more disciplines, while positioning the graduate to embark upon specialization in one area. Additional specialist training can readily be acquired later, but the habit of lateral thought cannot - it must come first. Only some students will wish to follow this track into science, which makes its own special intellectual demands, but they will be better for doing so.

Nicholas J. Kuhn

School of Biosciences, University of Birmingham, Birmingham B15 2TT, UK

1. Nature 403, 483 (2000)

\section{Religion has its place but don't pretend it's science}

Sir - I protest most strongly at Geoffrey Cantor's statement in his Millennium Essay $^{1}$ that I have made tirades against religion and that I regard it as the enemy of science. This is simply false; see what I have written on this topic, as in my Unnatural Nature of Science (Faber, London, 1993).

I do, however, follow David Hume, who made clear that religion is based on faith, science on reason. I only oppose religion in relation to science when people make scientific claims for it, for example in supporting creationism.

Lewis Wolpert

Department of Anatomy and Developmental

Biology, University College London, Gower Street, London WC1E 6BT, UK

1. Nature 403,831 (2000). 